\title{
Educational Comics in Text-Based Learning to Develop Speaking Skills for Elementary School Students
}

\author{
Desy Prastiti Setiarini ${ }^{1}$, Kuntoro ${ }^{2}$, Riptina Pawestri ${ }^{3}$, Upik Aimanah ${ }^{4}$ \\ \{ $\underline{\text { ibunefarhan@gmail.com }}{ }^{1}, \underline{\text { kuntorosutaryo@gmail.com }}{ }^{2}$, riptina.2305@ gmail.com ${ }^{3}$, \\ upik.aima@gmail.com ${ }^{4}$ \} \\ ${ }^{1}$ SD Negeri 1 Kejobong, Purbalingga, Indonesia \\ ${ }^{2}$ Magister Pendidikan Dasar, Universitas Muhammadiyah Purwokerto \\ ${ }^{3}$ SD Negeri 1 Bancarkembar, Banyumas, Indonesia \\ ${ }^{4}$ SD Negeri 1 Karangnangka, Purbalingga, Indonesia
}

\begin{abstract}
The research aims to develop speaking skills for elementary school students with educational comics in text-based learning. Teachers need teaching materials to complement teaching, while students need teaching materials as an insight enhancer in understanding the subject matter. This research was made because it saw the condition of many students who did not have good speaking skills, especially in conveying ideas. The strategy utilized in this investigate is library investigate strategy. This study makes library materials the main data source. The data obtained were collected, analyzed, and concluded to get conclusions about the literature study. Based on the research results, literature studies from several research results and journal articles show that the use of educational comics teaching materials can develop speaking skills for elementary school students in text-based learning.
\end{abstract}

Keywords: speaking skills, text-based learning, educational comics

\section{Introduction}

In the 2013 curriculum, Indonesian language learning emphasizes text-based learning. Text-based language learning is learning that allows students to master and use this type of text in society [1]. This is closely related to language skills, namely listening, speaking, reading, and writing skills.

One of the language skills a person has is speaking skills. Speaking skills are commonly used to communicate in everyday life. A person is said to have speaking skills if he is skilled at choosing language sounds (in the form of words, sentences, as well as stress and tone) appropriately and to formulate them appropriately to convey thoughts, feelings, ideas, facts, actions in a certain communication context (2 ]. Everyone who wants to practice in earnest can be skilled at speaking [3]. Speaking is the most important and essential skill, mastery in this skill describes the speaker who has more precise knowledge [4]. Achieving speaking skills competencies can also help students to support other skills such as reading and writing.

In fact, until now teachers have not maximized the use of teaching materials in Indonesian language learning. This has an impact on the speaking skills of elementary school students in general not optimal. This is caused by the difficulties experienced by students in understanding the material, students lack self-confidence, feel inferior, students are still afraid to convey ideas. Based on this fact, it is necessary to conduct research to develop the speaking skills of second grade students of SD Negeri 1 Kejobong. 
In connection with this problem the teacher must have creativity in making teaching materials [5]. Teaching materials are all forms of material used to assist teachers in carrying out teaching and learning activities in the classroom [6]. One alternative teaching material that grade II elementary school teachers can choose is educational comics. Many children like stories in comic form [7]. Educational comics have educational content and information related to the subject of the lesson, so they are suitable for use as learning media [8]. One of the advantages of comics is that they can motivate students during the learning process [9].

\section{Methods}

This research was conducted at SD Negeri 1 Kejobong, Kejobong District, Purbalingga Regency. The research time was carried out for 2 months, namely March-April 2021. The method used in this research is library research. The research stages include topic selection, information exploration, determining research focus, collecting data sources, preparing data presentation, and compiling reports [10]. The research stage was carried out by collecting literature sources, both primary and secondary [11]. The main data taken is based on the results of previous research, literature studies from several research results, and journal articles. The data analysis technique used in this literature research is the content analysis method [12]. In content analysis, text tracing is more than just a study of theory and methodology, content analysis as well as utilizing the earlier literature sources as study material [13].

\section{Results and Discussion}

The results of the study obtained a literature study (library research) which was carried out in March-April 2021. Based on the research data collected, it was shown that the expected speaking ability of learn at school is for students to be skilled at speaking. The expected speaking skill is the ability to express opinions, ideas, ideas, thoughts, or feelings in public in good and correct Indonesian [14].

Saputro and Soeharto argued that learning media packaged in comic form can be used as a variety of teaching media [15]. Besides, comics or picture stories are a very helpful medium for an effective learning process because comics are in great demand and attract the attention of students in elementary schools [16].

The use of educational comic teaching materials can develop speaking skills for elementary school students in text-based learning. As the results of research conducted by Pandanwangi et al. stated that the Indonesian comic media developed is suitable for use to help students improve their language competence. Comic learning media that are compiled from the aspects of listening, speaking, reading, and writing can be obtained by indicators based on the material, namely: (1) Mimicking dialogue in comics, (2) Telling events / games in comics, (3) Answering questions in reading comics, (4) rewriting the contents of the story in comics in their own language [17].

Suwarti, et al argued that the developed comics are really needed by students and teachers, are very valid, and very effective [18]. Then, Ummu Haniyyah stated that students who use comic media in the learning process experienced an increase in learning activities. The activities of students who use comic learning media show better activeness than students who do not use comic media during the learning process [19].

Research conducted by Wardhani et al. (2021) concluded that talking aptitudes are abilities that bolster rudimentary school understudy communication. To create talking abilities, a jolt is required that can prepare the talking abilities of rudimentary school understudies. One way to construct talking abilities is through comics. Comic media can stimulate students in expressing ideas and ideas from a story [20]. 
According to Prabawardani et al., there is a significant effect of comic-assisted storytelling method on Indonesian speaking skills between groups of students who are taught using comic-assisted storytelling method and groups of students who are taught using comicassisted storytelling method [21]. With comic stories that seem light and often occur around students, they can make it easier for students to understand these events, so that they can retell the content of the story.

\section{Conclusions}

Based on the background of the problem and the results of the literature study, it can be concluded that through the use of teaching materials in text-based learning using educational comics can develop speaking skills for elementary school students. The author hopes that this paper can be helpful to teachers and related parties in overcoming the problem of speaking skills for second-grade elementary school students.

\section{References}

[1] Ramadania F. Konsep bahasa berbasis teks pada buku ajar kurikulum 2013. Stilistika: Jurnal Bahasa, Sastra, dan Pengajarannya. 2016 Oct 1;1(2).. Mulyati Y. Hakikat keterampilan berbahasa. Jakarta: PDF Ut. ac. id hal. 2014;1

[2] Mulyati,Y 2018 Hakikat Keterampilan Berbahasa. Modul 1, 1.7.

[3] Tambunan P. Pembelajaran keterampilan berbicara di sekolah dasar. Jurnal Curere. 2018 Jul 5;2(1).

[4] Muna EN, Degeng IN, Hanurawan F. upaya peningkatan keterampilan berbicara menggunakan media gambar siswa Kelas IV SD. Jurnal Pendidikan: Teori, Penelitian, dan Pengembangan. 2019 Nov 1;4(11):1557-61.

[5] Lubis MA. Pengembangan Bahan ajar komik untuk meningkatkan minat baca ppkn siswa min ramba padang kabupaten tapanuli selatan. Jurnal Tarbiyah. 2018 Dec 15;25(2)..

[6] Nurdyansyah N. Pengembangan Bahan Ajar Modul Ilmu Pengetahuan Alambagi Siswa Kelas Iv Sekolah Dasar. Universitas Muhammadiyah Sidoarjo. 2018.

[7] Arya Pageh W, Gede YK. The digital comic Tantri Kamandaka: A discovery for national character education. International Journal of Innovation, Creativity and Change. 2020;13(03):718-32.

[8] Ilyana S, Sari RC. Pengembangan Komik Edukasi Sebagai Media Pembelajaran Literasi Keuangan Untuk Siswa Sekolah Dasar. Jurnal Pendidikan Akuntansi Indonesia. 2015;13(2).

[9] Ntobuo NE, Arbie A, Amali LN. The development of gravity comic learning media based on Gorontalo culture. Jurnal Pendidikan IPA Indonesia. 2018 Jul 16;7(2):246-51.

[10] Kuhltau, C. C. 2002. Teaching The Library Research. USA: Scarecrow Press Inc.

[11] Darmalaksana W. Metode Penelitian Kualitatif Studi Pustaka dan Studi Lapangan. Pre-Print Digital Library UIN Sunan Gunung Djati Bandung. 2020.

[12] Putri AE. Evaluasi Program Bimbingan dan Konseling: Sebuah Studi Pustaka. Jurnal bimbingan konseling indonesia. 2019 Sep;4(2):3942.

[13] Ahmad J. Desain penelitian analisis isi (Content analysis). Research Gate. 2018 Jun;5(9).

[14] Tambunan P. Pembelajaran keterampilan berbicara di sekolah dasar. Jurnal Curere. 2018 Jul 5;2(1).

[15] Saputro HB, Soeharto S. Pengembangan media komik berbasis pendidikan karakter pada pembelajaran tematik-integratif kelas IV SD. Jurnal Prima Edukasia. 2015 Jan 1;3(1):61-72.

[16] Prasetyo A. Pengembangan Media Komik Bermuatan Gender Dalam Peningkatan Keterampilan Bercerita Siswa Sekolah Dasar Tingkat Tinggi. Seloka: Jurnal Pendidikan Bahasa dan Sastra Indonesia. 2012;1(2).

[17] Pandanwangi N. A., Kristin F, Anugraheni I. PENGEMBANGAN MEDIA KOMIK UNTUK MENINGKATKAN KOMPETENSI BERBAHASA PADA SISWA KELAS 3 SD. JURNAL CAKRAWALA PENDAS Volume 5 Nomor 2 Edisi Juli 2019.

[18] Suwarti S, Laila A, Permana EP. Pengembangan Media Komik Berbasis Kearifan Lokal untuk Menentukan Pesan dalam Dongeng pada Siswa Sekolah Dasar. Profesi Pendidikan Dasar. 2020 Dec 20;7(2):140-51. 
[19] Haniyyah WU. PENGARUH PENGGUNAAN MEDIA PEMBELAJARAN KOMIK TERHADAP AKTIVITAS BELAJAR SISWA SEKOLAH DASAR. InSEMINAR NASIONAL PGSD UNIMED (Vol. 2, No. 1, pp. 150-155).

[20] Wardhani, P. A., dkk 2021 COMIC STORY UNTUK MENINGKATKAN KEMAMPUAN BERCERITA BAGI SISWA SEKOLAH DASAR. Diglosia Jurnal Pendidikan, Kebahasaan, dan kesusastraan Indonesia Vol. 5, No. 1, Februari 2021.

[21] Prabawardani, K., dkk 2018 PENGARUH METODE STORYTELLING BERBANTUAN KOMIK TERHADAP KETERAMPILAN BERBICARA BAHASA NDONESIA SISWA KELAS V. Jurnal EDUTECH Universitas Pedidikan Ganesha. Vol. 6 No. (2) pp. 147-158. 